\title{
Urinary Level of Tumor Necrosis Factor Alpha in Patients with Type -2 Diabetic Nephropathy
}

\author{
Youssef Khalel Ahmed ${ }^{1}$, Amin Mahmoud Amin Hegazy', Mohammed Abdel-Hamed Keder ${ }^{2}$ \\ and Mohamed Ahmed Mohamed Moustafa ${ }^{1}$
}

Departments of Internal Medicine ${ }^{1}$ and Clinical Pathology ${ }^{2}$ Faculty of Medicine, Al-Azhar University, Cairo, Egypt.

Corresponding author: Mohamed Ahmed Mohamed Moustafa, E-mail: aboaiana@gmail.com

\begin{abstract}
Background: Diabetic nephropathy is the principal cause of end stage renal disease (ESRD) in the Western world, with renal disease as a major cause of morbidity and mortality in the diabetic population. Inflammation is a potential factor in the development and progression of DN and recent data indicate that diabetes includes an inflammatory component which may contribute to diabetic complications.

Objectives: Aiming to investigate possible correlation between the presence and degree of albuminuria and urinary tumor necrosis factor-alpha as a marker of inflammation in diabetic nephropathy in type 2 diabetes mellitus.

Patients and Methods: This study was conducted at El-Hussein University Hospital on 60 patients with type- 2 diabetes mellitus and 20 healthy volunteers for the matched age and sex. Diabetic patients were divided into 3 groups according to the degree of proteinuria. Controls: 20 healthy controls, Group A: 20 type 2 diabetic patients without albuminuria, Group B: 20 type 2 diabetic patients with microalbuminuria. Group C: 20 type 2 diabetic patients with macro-albuminuria.

Results: urinary TNF-alpha and serum hs-CRP were significantly higher in diabetic than controls. It was also significantly higher in patients with macroalbuminuria than those with microalbuminuria and normoalbuminuria. There was significant positive correlation between urinary TNF- $\alpha$ and urine protein excretion in diabetic patients as well as age, CRP, duration of diabetes and glycemic control.

Conclusion: urinary TNF- $\alpha$ is independently and significantly correlated with the presence and degree of albuminuria in diabetic nephropathy in type 2 diabetes mellitus. This suggests that TNF- $\alpha$ play a significant role in the pathogenesis and progression of renal injury in diabetes.
\end{abstract}

Keywords: Diabetic nephropathy; Tumor necrosis factor-alpha.

\section{Introduction}

Diabetic nephropathy (DN) is a metabolic disorder with high morbidity and mortality. Global pattern of diabetic nephropathy incidence is not entirely explored, but its incidence has already occurred widely and is estimated to be increased in prevalence. It occurs in $20-40 \%$ of people with type 2 diabetes mellitus (DM) and the most frequent cause of end stage renal disease (ESRD) ${ }^{(1,2)}$. Until recently, diabetic nephropathy has been exclusively attributed to the interaction between metabolic parameters (activation of polyols, exozamines, diacylglycerols, and advanced glycosylated end products-AGEs) hemodynamic factors (systemic hypertension, intraglomerular hemodynamic changes, angiotensin II, endothelin I), and oxidative stress, governed by genetic and environmental factors. However, more recent evidence suggested that chronic subclinical inflammation may play a key role in the initiation and progression of diabetic nephropathy. Tubulointerstitial infiltration by inflammatory cells is evident in renal biopsies from patients with diabetic nephropathy ${ }^{(3)}$.

The interest for the use of biomarkers for early DN derives from the observation that patients with type 2 diabetes pass through a period of pre-diabetes and may experience renal impairment at the time of diagnosis. Although microalbuminuria has been considered as the earliest marker of DN in clinical practice, 29.1$61.6 \%$ of individuals with type 2 diabetes could have renal impairment even before the onset of microalbuminuria $^{(4)}$.

Thus, it is necessary to implement different strategies for detecting early $\mathrm{DN}$ in patients with type 2 diabetes aiming to delay its progression and improve outcomes. Increased levels of urinary biomarkers can be detected in type 2 diabetic patients before the onset of 
significant albuminuria and may be used as an early marker of renal injury in DN, this would play a significant role for the effective management and treatment approaches in diabetic care ${ }^{(5)}$.

TNF- $\alpha$ is a pleiotropic inflammatory cytokine (is a 157 amino-acid peptide) that is mainly produced by monocytes, macrophages, and $\mathrm{T}$ cells. In addition, and similar to other inflammatory cytokines, the expression and synthesis of tumor necrosis factor alpha (TNF$\alpha$ ) is not limited to hematopoietic cells. Thus, intrinsic renal cells, including mesangial, glomerular, endothelial, dendritic, and renal tubular cells are able to produce this cytokine (6).

Within the glomerulus, TNF- $\alpha$ displays a number of effects that are relevant to the manifestations observed at the initial stages and during the progression of glomerular injury. TNF- $\alpha$ is implicated in the misbalance between vasodilator and vasoconstrictor mediators, which may result in alterations of glomerular blood flow and glomerular filtration rate. Additionally, this cytokine is cytotoxic to glomerular, mesangial and epithelial cells, and may induce direct renal damage. Also TNF- $\alpha$ is able to promote the local generation of reactive oxygen species, which affects the barrier function of the glomerular capillary wall resulting in enhanced albumin permeability, independently of hemodynamic factors or effects of recruited inflammatory cells. Regarding tubuleinterstitial damage, exposure of tubular epithelial cells to TNF- $\alpha$ increased the synthesis and secretion of lymphocyte and neutrophil chemoattractant factors as well as the cell surface expression of intercellular adhesion molecule-1, which has been implicated in the development of renal injury in diabetes. Finally, TNF- $\alpha$ has stimulatory effects on sodium uptake by proximal tubule cells, contributing to sodium retention and renal hypertrophy, typical alterations that occur during the early stage of $\mathrm{DN}^{(7,8)}$.

\section{Aim of the work}

The present study was performed to investigate possible correlation between the presence and degree of albuminuria and urinary TNF-alpha as a marker of inflammation in DN in type 2 DM.

\section{Ethical approval}

This study was implemented along with the Ethical Committee guidelines of the Faculty of Medicine, Al-Azhar University, Cairo, Egypt. All clinical interventions were illustrated to all participants prior to study implementation. A written informed consent after a clear explanation of all study steps was obtained.

This study which was carried out at the inpatient departments and outpatient clinics of El-Hussein University Hospital (Al-Azhar University Hospital) from January 2019 to end of August 2019.

This study was conducted on 60 type-2 DM and 20 healthy control subjects with matched age and sex, the age was (54.3 \pm 1.92 years) and sex (male to female 11:9). Diabetic patients were divided into 3 groups: Group A: 20 type 2 diabetic patients without albuminuria, the age was $(55.8 \pm 2.4$ years) and sex (male to female 12:8). Group B: 20 type 2 diabetic patients with microalbuminuria, the age was $(60.3 \pm 1.87$ years) and sex (male to female 9:11) and Group C: 20 type 2 diabetic patients with macroalbuminuria, the age was $(59.81 \pm 2.41$ years) and sex (male to female 13:7).

To avoid potential confounding factors, we excluded patients with current acute illness (including infections), current cigarette smoking, immunologic or malignant diseases, morbid cardiovascular illness, medical history of clinical cardiovascular events (cardiac, cerebral or peripheral vascular disease) in the last 6 months, and patients on angiotensin converting enzyme inhibitors (ACEi), angiotensin receptor antagonists or nonsteroidal anti-inflammatory drugs (NSAIDs).

Relevant clinical history and examination were recorded. Arterial blood pressure and BMI was measured. Complete blood count, alanine aminotransferase (ALT), aspartate aminotransferase (AST), serum albumin, serum bilirubin, serum Creatinine, Lipid profile, CRP. Glycemic control was assessed by glycosylated hemoglobin (HbA1c). Proteinuria was measured by albumin dipsticks, urinary microalbumin kits and albumin/creatinine ratio (Alb/Cr ratio) in morning urine sample. Pelvic and abdominal ultrasonographic examination was done for all subjects. 
Estimation of urine TNF- $\alpha$ was drawn from 24$\mathrm{hr}$ urine collections. After collection, the samples were centrifuged at 3000 r.p.m. for 10 min and the supernatant was stored at $20^{\circ} \mathrm{C}$. Enzyme-linked immunosorbent assay (ELISA) was used for the detection of urinary TNF- $\alpha$. Estimation of serum high sensitivity C-reactive protein (hs-CRP) was done for all subjects by enzyme-linked immunosorbent assay (ELISA).

\section{Statistical analysis:}

Data were analyzed using Statistical Package for Social Science (SPSS) version 20.0. Quantitative data were expressed as mean \pm standard deviation (SD). Qualitative data were expressed as frequency and percentage.

The following tests were done:

- A one-way analysis of variance (ANOVA) when comparing between more than two means.

- Chi-square (X2) test of significance was used in order to compare proportions between two qualitative parameters.

- Pearson's correlation coefficient (r) test was used for correlating data.

- Probability (P-value)

- P-value $<0.05$ was considered significant.
- P-value <0.001 was considered as highly significant.

- P-value >0.05 was considered insignificant.

\section{Results}

General characteristics and parameters of healthy non-diabetic controls and diabetic patients stratified by albuminuria status are depicted in (Table 1).

$\mathrm{BMI}, \mathrm{ABP}, \mathrm{HbA1c}, \mathrm{Alb} / \mathrm{Cr}$ ratio, urinary TNF$\alpha$, and CRP were highly statistically significantly higher ( $\mathrm{p}$-value $<0.001$ ) in all patients groups than controls. Disease duration, $\mathrm{BMI}, \mathrm{ABP}, \mathrm{HbA1c}, \mathrm{Alb} / \mathrm{Cr}$ ratio, urinary TNF$\alpha$, eGFR and CRP were significantly higher in GII than GI and in GIII than G II (p-value < 0.001) (Table 2, 3).

There was significant positive correlation between urinary TNF- $\alpha$ and of urine protein excretion in diabetic patients as well as age, CRP, duration of diabetes and glycemic control. CRP Positively correlated with $\mathrm{HbAlc}$ and Alb/Cr ratio (Table 4, 5 and Fig. 1, 2, 3).

After forward stepwise multiple regression analysis, urine TNF- $\alpha$ remained as independent predictors of $\mathrm{Alb} / \mathrm{Cr}$ ratio among patients in groups Urinary TNF- $\alpha$ levels were significantly and positively correlated to $\mathrm{HbA} 1 \mathrm{C}$ levels.

Table (1): The collective data of Control group and other studied groups

\begin{tabular}{|l|c|c|c|c|}
\hline & $\begin{array}{c}\text { Control } \\
(\mathrm{N}=20)\end{array}$ & $\begin{array}{c}\text { Group I } \\
(\mathrm{N}=20)\end{array}$ & $\begin{array}{c}\text { Group II } \\
(\mathrm{N}=20)\end{array}$ & $\begin{array}{c}\text { Group III } \\
(\mathrm{N}=20)\end{array}$ \\
\hline
\end{tabular}




\begin{tabular}{|c|c|c|c|c|c|}
\hline Duration (years) & Mean \pm SD & ----- & $7.14 \pm 1.38$ & $10.45 \pm 1.23$ & $13.48 \pm 1.41$ \\
\hline BMI $\left(\mathrm{kg} / \mathrm{m}^{2}\right)$ & Mean \pm SD & $25.75 \pm 1.55$ & $27.52 \pm 1.53$ & $27.81 \pm 1.09$ & $27.99 \pm 1.16$ \\
\hline $\mathrm{SBP}(\mathrm{mmHg})$ & Mean \pm SD & $121.15 \pm 9.71$ & $132.3 \pm 4.05$ & $139.1 \pm 4.22$ & $139.75 \pm 5.95$ \\
\hline$\overline{\mathrm{DBP}}(\mathrm{mmHg})$ & Mean \pm SD & $75.5 \pm 5.60$ & $85.15 \pm 5.66$ & $87.0 \pm 4.97$ & $82.25 \pm 11.97$ \\
\hline $\operatorname{HbA1C}(\%)$ & Mean \pm SD & $5.53 \pm 0.11$ & $7.69 \pm 0.35$ & $8.64 \pm 0.55$ & $8.65 \pm 0.76$ \\
\hline $\mathrm{Alb} / \mathrm{Cr}$ ratio(mg/g) & Mean \pm SD & $15.35 \pm 3.74$ & $23.55 \pm 4.97$ & $235.95 \pm 6.38$ & $1913.25 \pm 76.1$ \\
\hline Urinary TNF- $\alpha(\mathrm{pg} / \mathrm{ml})$ & Mean \pm SD & $25.3 \pm 4.51$ & $261.5 \pm 24.77$ & $473.78 \pm 37.48$ & $646.9 \pm 40.64$ \\
\hline eGFR (ml/min/1.73m2) & Mean \pm SD & $\begin{array}{ll}------ \\
\end{array}$ & $110.7 \pm 10.9$ & $99.2 \pm 4.87$ & $90.2 \pm 5.3$ \\
\hline CRP (mg/dl) & Mean \pm SD & $1.05 \pm 0.25$ & $2.92 \pm 0.49$ & $4.99 \pm 0.40$ & $6.99 \pm 0.62$ \\
\hline ALT (U/L) & Mean \pm SD & $21.8 \pm 4.5$ & $21.8 \pm 4.4$ & $21.0 \pm 4.1$ & $21.6 \pm 3.8$ \\
\hline$\overline{\mathrm{AST}}(\mathrm{U} / \mathrm{L})$ & Mean \pm SD & $19.4 \pm 3.9$ & $22.1 \pm 4.1$ & $21.5 \pm 4.3$ & $21.6 \pm 3.8$ \\
\hline Albumin (g/dl) & Mean \pm SD & $4.2 \pm 0.3$ & $4.0 \pm 0.3$ & $4.0 \pm 0.3$ & $3.4 \pm 0.2$ \\
\hline Bilirubin (mg/dl) & Mean \pm SD & $1.0 \pm 0.3$ & $1.0 \pm 0.2$ & $1.0 \pm 0.2$ & $1.0 \pm 0.2$ \\
\hline S. creatinine $(\mathrm{mg} / \mathrm{dl})$ & Mean \pm SD & $1.0 \pm 0.2$ & $1.2 \pm 0.2$ & $1.3 \pm 0.2$ & $1.6 \pm 0.1$ \\
\hline Urea (mg/dl) & Mean \pm SD & $14.2 \pm 4.4$ & $13.6 \pm 4.4$ & $13.4 \pm 4.2$ & $15.4 \pm 3.5$ \\
\hline HB \%(million/cm) & Mean \pm SD & $13.2 \pm 1.6$ & $13.3 \pm 1.5$ & $12.6 \pm 1.4$ & $10.9 \pm 0.8$ \\
\hline Plat $\left(\mathrm{x} 10^{3} / \mathrm{cm}\right)$ & Mean \pm SD & $234.4 \pm 55.8$ & $242.4 \pm 52.6$ & $254.8 \pm 52.2$ & $263.8 \pm 40.8$ \\
\hline WBC $\left(\times 10^{3} / \mathrm{cm}\right)$ & Mean \pm SD & $5.7 \pm 1.8$ & $5.5 \pm 1.8$ & $5.4 \pm 1.6$ & $5.3 \pm 1.7$ \\
\hline CHOL (mg/dl) & Mean \pm SD & $213.4 \pm 6.2$ & $214.1 \pm 7.7$ & $212.7 \pm 7.1$ & $196.3 \pm 6.6$ \\
\hline HDL (mg/dl) & Mean \pm SD & $58.8 \pm 7.2$ & $59.1 \pm 6.6$ & $58.0 \pm 7.7$ & $62.0 \pm 6.7$ \\
\hline LDL (mg/dl) & Mean \pm SD & $149.7 \pm 20.3$ & $150.7 \pm 17.8$ & $150.2 \pm 19.8$ & $147.0 \pm 18.3$ \\
\hline
\end{tabular}

Table (2): Comparison between Controls and other studied groups as regard studied data

\begin{tabular}{|l|c|c|c|c|c|}
\hline Variables & $\begin{array}{c}\text { Control } \\
(\mathrm{N}=20)\end{array}$ & $\begin{array}{c}\text { Group I } \\
(\mathrm{N}=20)\end{array}$ & $\begin{array}{c}\text { Group II } \\
(\mathrm{N}=20)\end{array}$ & $\begin{array}{c}\text { Group III } \\
(\mathrm{N}=20)\end{array}$ & P-value \\
\hline
\end{tabular}


ejhm.journals.ekb.eg

\begin{tabular}{|c|c|c|c|c|c|c|}
\hline \multirow[b]{2}{*}{$\operatorname{BMI}\left(\mathrm{kg} / \mathrm{m}^{2}\right)$} & Mean & 25.75 & 27.52 & 27.81 & 27.99 & \multirow{2}{*}{$\begin{array}{c}\mathrm{P} 1< \\
0.001(\mathrm{HS}) \\
\mathrm{P} 2<0.001 \\
(\mathrm{HS}) \\
\mathrm{P} 3<0.001 \\
(\mathrm{HS})\end{array}$} \\
\hline & $\pm \mathrm{SD}$ & 1.55 & 1.53 & 1.09 & 1.16 & \\
\hline \multirow[b]{2}{*}{$\mathrm{SBP}(\mathrm{mmHg})$} & Mean & 121.15 & 132.30 & 139.10 & 139.75 & \multirow{2}{*}{$\begin{aligned} \mathrm{P} 1 & <0.001 \\
& (\mathrm{HS}) \\
\mathrm{P} 2 & <0.001 \\
& (\mathrm{HS}) \\
\mathrm{P} 3 & <0.001 \\
& (\mathrm{HS})\end{aligned}$} \\
\hline & $\pm \mathrm{SD}$ & 9.71 & 4.05 & 4.22 & 5.95 & \\
\hline Duration (years) & $\begin{array}{c}\text { Mean } \\
\pm \text { SD }\end{array}$ & ----- & $7.14 \pm 1.38$ & $10.45 \pm 1.23$ & $13.48 \pm 1.41$ & \\
\hline \multirow[b]{2}{*}{ DBP (mmHg) } & Mean & 75.50 & 85.15 & 87.00 & 82.25 & \multirow{2}{*}{$\begin{array}{c}\mathrm{P} 1<0.001 \\
(\mathrm{HS}) \\
\mathrm{P} 2<0.001 \\
\quad(\mathrm{HS}) \\
\mathrm{P} 3=0.006 \\
\quad(\mathrm{~S})\end{array}$} \\
\hline & $\pm \mathrm{SD}$ & 5.60 & 5.66 & 4.97 & 11.97 & \\
\hline \multirow[b]{2}{*}{$\operatorname{HbA1C}(\%)$} & Mean & 5.53 & 7.69 & 8.64 & 8.65 & \multirow{2}{*}{$\begin{aligned} \mathrm{P} 1 & <0.001 \\
& (\mathrm{HS}) \\
\mathrm{P} 2 & <0.001 \\
& (\mathrm{HS}) \\
\mathrm{P} 3 & <0.001 \\
& (\mathrm{HS})\end{aligned}$} \\
\hline & $\pm \mathrm{SD}$ & 0.11 & 0.35 & 0.55 & 0.76 & \\
\hline \multirow[b]{2}{*}{ Alb/Cr ratio (mg/g) } & Mean & 15.35 & 23.55 & 235.95 & 1913.25 & \multirow{2}{*}{$\begin{array}{c}\mathrm{P} 1=0.929 \\
\quad(\mathrm{NS}) \\
\mathrm{P} 2=0.019 \\
\quad(\mathrm{~S}) \\
\mathrm{P} 3<0.001 \\
\quad(\mathrm{HS})\end{array}$} \\
\hline & $\pm \mathrm{SD}$ & 5.74 & 4.97 & 6.38 & 76.10 & \\
\hline \multirow[b]{2}{*}{$\begin{array}{l}\text { Urinary TNF- } \\
\alpha(\mathrm{pg} / \mathrm{ml})\end{array}$} & Mean & 25.30 & 261.50 & 473.78 & 646.90 & \multirow{2}{*}{$\begin{array}{c}\mathrm{P} 1<0.001 \\
\quad(\mathrm{HS}) \\
\mathrm{P} 2<0.001 \\
\quad(\mathrm{HS}) \\
\mathrm{P} 3<0.001 \\
(\mathrm{HS})\end{array}$} \\
\hline & $\pm \mathrm{SD}$ & 4.51 & 24.77 & 37.48 & 40.64 & \\
\hline \multirow[b]{2}{*}{$\mathrm{CRP}(\mathrm{mg} / \mathrm{dl})$} & Mean & 1.05 & 2.92 & 4.99 & 6.99 & \multirow{2}{*}{$\begin{array}{c}\mathrm{P} 1<0.001 \\
(\mathrm{HS}) \\
\mathrm{P} 2<0.001 \\
(\mathrm{HS}) \\
\mathrm{P} 3<0.001\end{array}$} \\
\hline & $\pm \mathrm{SD}$ & 0.25 & 0.49 & 0.40 & 0.62 & \\
\hline
\end{tabular}

P1: Control vs Group I

P2: Control vs Group II

P3: Control vs Group III

Table (3): Comparison between studied groups as regard studied data.

\begin{tabular}{|c|c|c|c|c|c|}
\hline \multicolumn{2}{|l|}{} & $\begin{array}{c}\text { Group I } \\
\text { Variables }\end{array}$ & $\begin{array}{c}\text { Group II } \\
(\mathrm{N}=20)\end{array}$ & $\begin{array}{c}\text { Group III } \\
(\mathrm{N}=20)\end{array}$ & P-value \\
\hline Duration (years) & Mean & 7.14 & 10.45 & 13.48 & $\mathrm{P} 1<0.001$ (HS) \\
\hline
\end{tabular}


ejhm.journals.ekb.eg

\begin{tabular}{|c|c|c|c|c|c|}
\hline & \pm SD & 1.38 & 1.23 & 1.41 & $\begin{array}{l}\mathrm{P} 2<0.001(\mathrm{HS}) \\
\mathrm{P} 3<0.001(\mathrm{HS})\end{array}$ \\
\hline \multirow{2}{*}{ BMI $\left(\mathrm{kg} / \mathrm{m}^{2}\right)$} & Mean & 27.52 & 27.81 & 27.99 & \multirow{2}{*}{$\begin{array}{l}\mathrm{P} 1=0.498(\mathrm{NS}) \\
\mathrm{P} 2=0.273(\mathrm{NS}) \\
\mathrm{P} 3=0.674(\mathrm{NS})\end{array}$} \\
\hline & \pm SD & 1.53 & 1.09 & 1.16 & \\
\hline \multirow{2}{*}{$\mathrm{SBP}(\mathrm{mmHg})$} & Mean & 132.30 & 139.10 & 139.75 & \multirow{2}{*}{$\begin{array}{c}\mathrm{P} 1=0.001(\mathrm{~S}) \\
\mathrm{P} 2<0.001(\mathrm{HS}) \\
\mathrm{P} 3=0.749(\mathrm{NS})\end{array}$} \\
\hline & $\pm \mathrm{SD}$ & 4.05 & 4.22 & 5.95 & \\
\hline \multirow{2}{*}{$\mathrm{DBP}(\mathrm{mmHg})$} & Mean & 85.15 & 87.00 & 82.25 & \multirow{2}{*}{$\begin{array}{l}\mathrm{P} 1=0.444(\mathrm{NS}) \\
\mathrm{P} 2=0.232(\mathrm{NS}) \\
\mathrm{P} 3=0.052(\mathrm{NS})\end{array}$} \\
\hline & \pm SD & 5.66 & 4.97 & 11.97 & \\
\hline \multirow{2}{*}{$\operatorname{HbA1C}(\%)$} & Mean & 7.69 & 8.64 & 8.65 & \multirow{2}{*}{$\begin{array}{l}\mathrm{P} 1<0.001(\mathrm{HS}) \\
\mathrm{P} 2<0.001(\mathrm{HS}) \\
\mathrm{P} 3=0.950(\mathrm{NS})\end{array}$} \\
\hline & $\pm \mathrm{SD}$ & 0.35 & 0.55 & 0.76 & \\
\hline \multirow{2}{*}{ Alb/Cr ratio } & Mean & 23.55 & 235.95 & 1913.25 & \multirow{2}{*}{$\begin{array}{c}\mathrm{P} 1=0.023(\mathrm{~S}) \\
\mathrm{P} 2<0.001(\mathrm{HS}) \\
\mathrm{P} 3<0.001(\mathrm{HS})\end{array}$} \\
\hline & \pm SD & 4.97 & 6.38 & 76.10 & \\
\hline \multirow{2}{*}{ Urinary TNF- $\alpha$} & Mean & 261.50 & 473.78 & 646.90 & \multirow{2}{*}{$\begin{array}{l}\mathrm{P} 1<0.001(\mathrm{HS}) \\
\mathrm{P} 2<0.001(\mathrm{HS}) \\
\mathrm{P} 3<0.001(\mathrm{HS})\end{array}$} \\
\hline & $\pm \mathrm{SD}$ & 24.77 & 37.48 & 40.64 & \\
\hline \multirow{2}{*}{$\begin{array}{c}\text { eGFR (ml/min } / 1.73 \\
\mathrm{~m} 2)\end{array}$} & Mean & 110.70 & 99.23 & 90.24 & \multirow{2}{*}{$\begin{array}{l}\mathrm{P} 1<0.001(\mathrm{HS}) \\
\mathrm{P} 2<0.001(\mathrm{HS}) \\
\mathrm{P} 3<0.001(\mathrm{HS})\end{array}$} \\
\hline & $\pm \mathrm{SD}$ & 10.98 & 4.87 & 5.31 & \\
\hline \multirow{2}{*}{ CRP (mg/dl) } & Mean & 2.92 & 4.99 & 6.99 & \multirow{2}{*}{$\begin{array}{l}\mathrm{P} 1<0.001(\mathrm{HS}) \\
\mathrm{P} 2<0.001(\mathrm{HS}) \\
\mathrm{P} 3<0.001(\mathrm{HS})\end{array}$} \\
\hline & \pm SD & 1.49 & 0.40 & 0.62 & \\
\hline
\end{tabular}

P1: Group I vs Group II P2: Group I vs Group III P2: Group II vs Group III 
Table (4): Correlation study between (Urinary TNF-alpha and other studied parameters) and (hs-CRP vs HbA1C and Alb/Cr ratio) in patients groups.

\begin{tabular}{|l|c|c|c|c|c|}
\hline \multicolumn{7}{|c|}{ Correlations } & $(\mathbf{r})$ & p-value & Correlations & $(\mathbf{r})$ & p-value \\
\hline $\begin{array}{l}\text { Urinary TNF- } \alpha \text { vs Alb/Cr } \\
\text { ratio }\end{array}$ & 0.83 & $<\mathbf{0 . 0 0 1} *$ & Urinary TNF- $\alpha$ vs GFR & -0.73 & $<\mathbf{0 . 0 0 1 *}$ \\
\hline Urinary TNF- $\alpha$ vs duration & 0.90 & $<\mathbf{0 . 0 0 1} *$ & & & \\
\hline Urinary TNF- $\alpha$ vs BMI & 0.16 & 0.24 & & & \\
\hline Urinary TNF- $\alpha$ vs HbA1C & 0.58 & $<\mathbf{0 . 0 0 1} *$ & hs-CRP vs HbA1C & 0.45 & $<\mathbf{0 . 0 0 1 *}$ \\
\hline $\begin{array}{l}\text { Urinary TNF- } \alpha \text { vs } \\
\text { hs-CRP }\end{array}$ & 0.88 & $<\mathbf{0 . 0 0 1 *}$ & hs-CRP vs Alb/Cr ratio & 0.73 & $<\mathbf{0 . 0 0 1 *}$ \\
\hline
\end{tabular}

*: p-value $<0.001$ is considered highly significant.

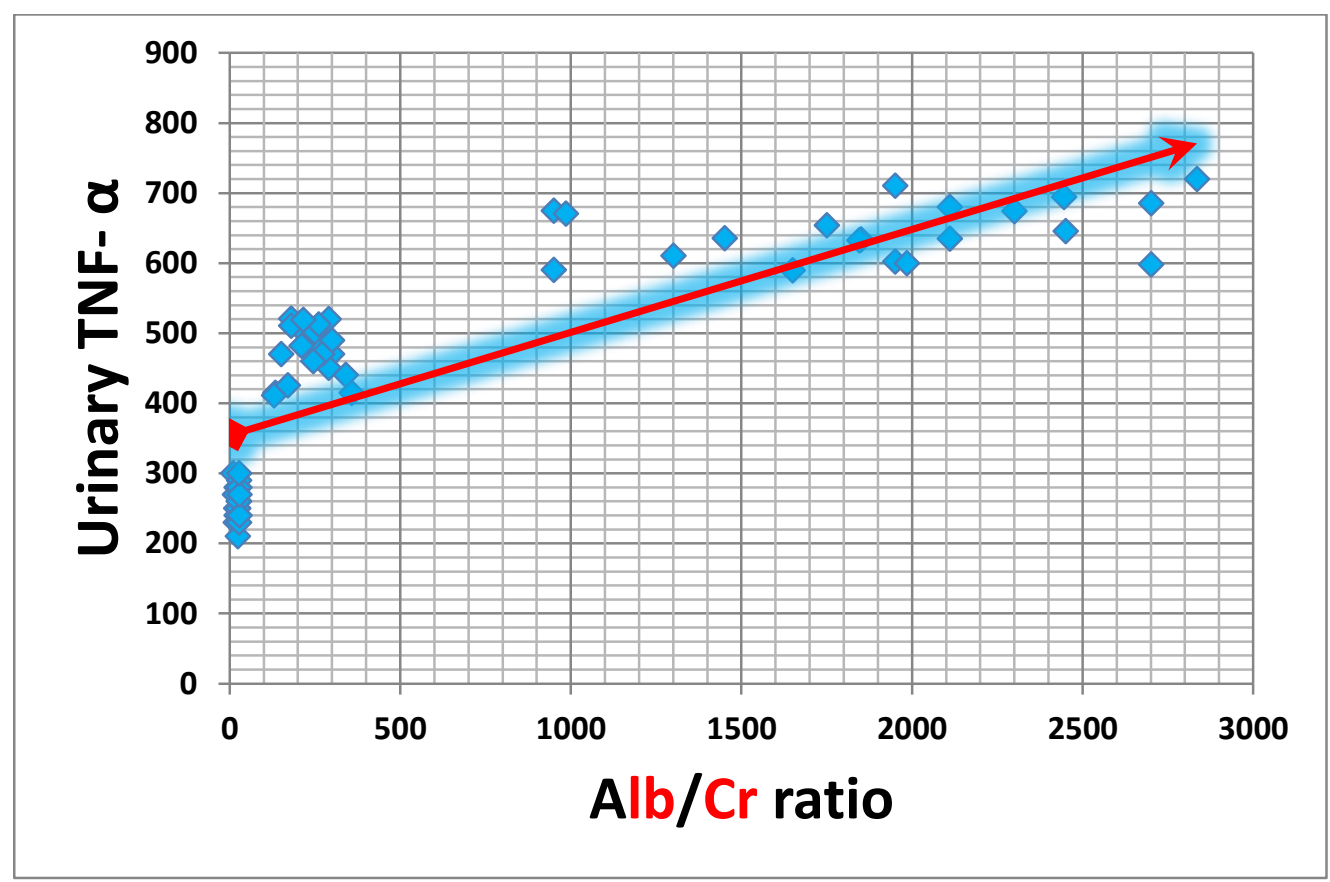

Figure (1): Positive correlation between Urinary TNF- $\alpha$ and Alb/Cr ratio in groups. $(p$-value $<0.001 *, r=0.83$ ) 


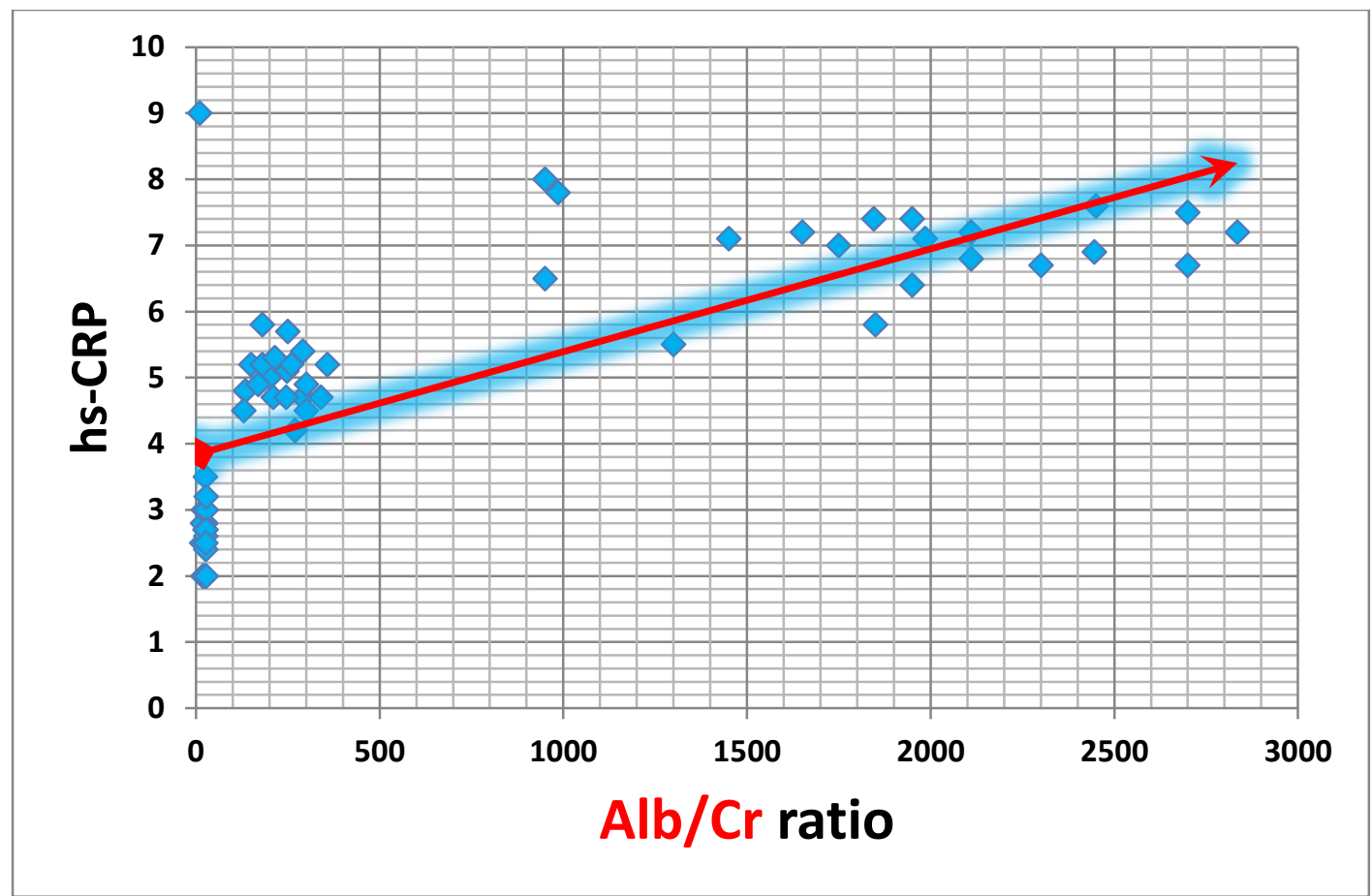

Figure (2): Positive correlation between hs-CRP and $\mathrm{Alb} / \mathrm{Cr}$ ratio in patients groups. $(p$-value $<0.001 *, r=0.73)$

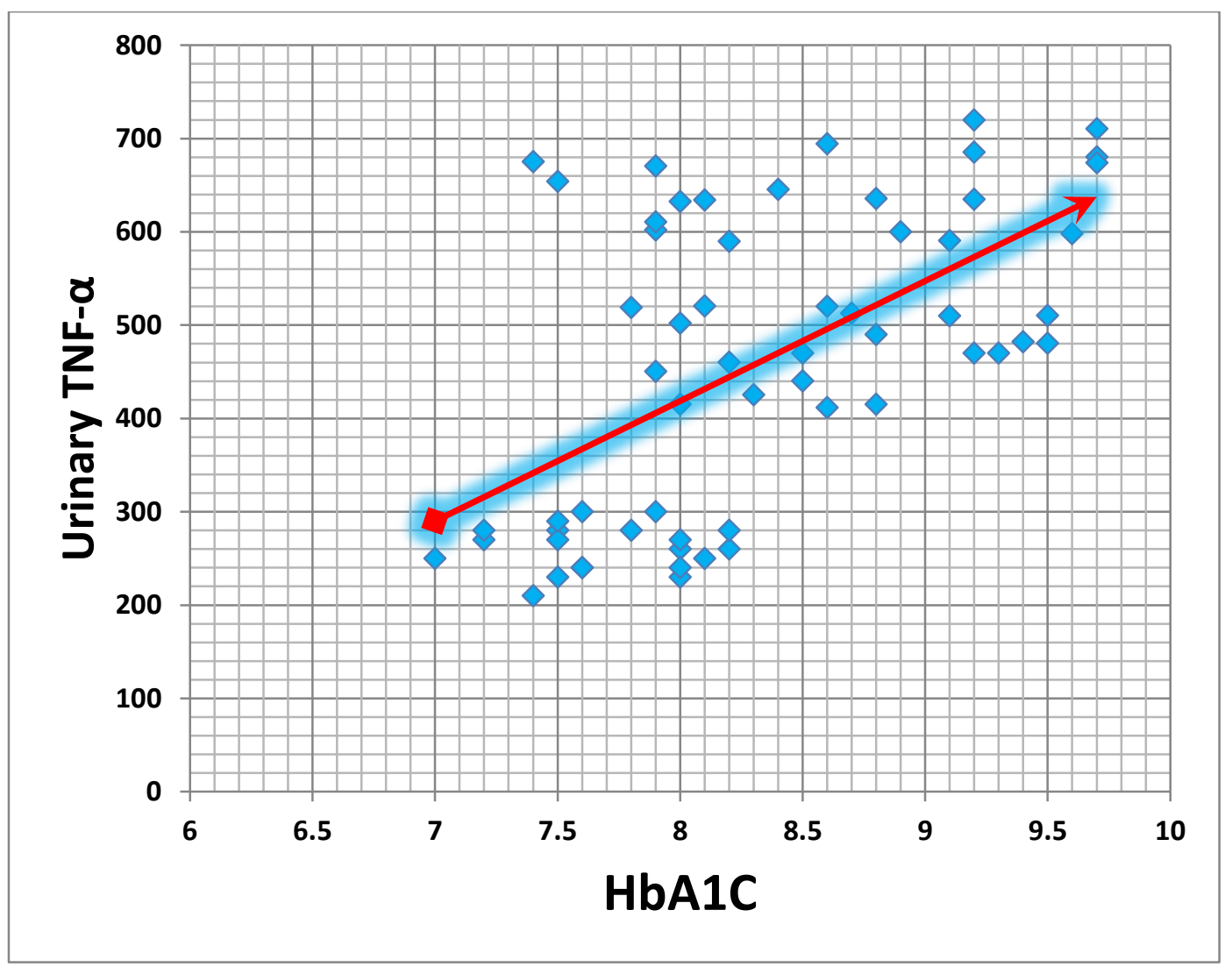

Figure (3): Positive correlation between urinary TNF- $\alpha$ and HbA1C in patients groups. (p-value $<0.001 *, r=0.58)$ 


\section{Discussion}

Diabetic nephropathy (DN) is the principal cause of ESRD in the Western world, with renal disease as a major cause of morbidity and mortality in the diabetic population. It was estimated that type 2 diabetes contributes to at least $50 \%$ of patients who have diabetes in endstage renal failure programs ${ }^{(6)}$.

The studies suggest a significant role of inflammation in the pathogenesis and progression of diabetic nephropathy. However, inflammation in diabetic nephropathy is activated by metabolic, biochemical, and hemodynamic disorders which progressively and persistently lead to kidney injury ${ }^{(3)}$. Human TNF- $\alpha$ is a polypeptide of 157 amino acid residues and a molecular weight of $17 \mathrm{kDa}$. TNF- $\alpha$ is produced by monocytes macrophages and by native renal cells (glomerular endothelial, mesangial and epithelial cells, and tubular epithelial cells) and stimulates them to produce other cytokines, growth factors, and chemokines, such as interleukin-8 (IL-8), monocyte chemo attractant protein (MCP)-1, and macrophage-colony stimulating factor (MCSF) ${ }^{(9)}$.

TNF-alpha up regulates the expression of endothelial and leukocyte adhesion molecules, which mediate the adhesion of monocytes, lymphocytes, and granulocytes to activated endothelium and their subsequent migration ${ }^{(\mathbf{1 0})}$. TNF-alpha may promote renal damage in diabetic nephropathy through several mechanisms. It stimulates the production of endothelin-1 and therefore vasoconstriction and reduction of glomerular blood flow and glomerular filtration rate. It has a cytotoxic effect on glomerular cells and stimulates apoptosis. It disrupts the intracellular junctions of the glomerular filtration barrier and increases its permeability resulting in the development of albuminuria $^{(\mathbf{1 1})}$.

The availability of highly sensitive assays resulted in that hs-CRP has become an exquisite marker of chronic subclinical inflammation.

In our study hs-CRP levels in type-2 diabetic patients with microalbuminuria and overt proteinuria was significantly greater than in diabetic patients without albuminuria and healthy individuals. Furthermore, there was a positive correlation between urinary TNF- $\alpha$ and hs-CRP level and urinary albumin excretion. These results are in agreement with the results of Navarro et al. ${ }^{(12)}$, who compared 65 type-2 diabetic patients and 21 healthy controls and found that urinary TNF- $\alpha$ and hs-CRP were significantly higher in diabetic than in control subjects. Also our study is supported by Refat et al. ${ }^{(8)}$, that compared 95 type-2 diabetic patients and 15 healthy controls and both found that's serum and urine TNF- $\alpha$ and hs-CRP levels are elevated in type- 2 diabetic patients and their levels correlate with markers of glomerular damage. They explained that it is important to note that this cytokine may be produced in the diabetic kidney by infiltrating cells (mainly macrophages) as well as intrinsically by renal cells (endothelial, mesangial, glomerular and tubular epithelial cells). This suggests a significant role for TNF$\alpha$ in the pathogenesis and progression of renal injury in diabetes mellitus. Urinary $\mathrm{TNF}-\alpha$ serves as a biomarker of renal inflammation, and predictors to detect early diabetic nephropathy in type 2 Diabetic Patient.

We also observed that the mean values of urine TNF- $\alpha$ and hs-CRP are higher in diabetics with proteinuria than those without albuminuria. Our results showed that urinary TNF- $\alpha$ is independently and significantly associated with albumin/creatinine ratio in Group I, Group-II and Group-III. The results of Lampropoulou et al. ${ }^{(3)}$ support our findings, as they observed a significant correlation between microalbuminuria and urinary TNF- $\alpha$ levels and the latter were higher in patients with microalbuminuria than in those with normoalbuminuria. Interestingly, in the present study multivariate analysis showed that urinary TNF- $\alpha$ was the only independent predictor of the degree of microalbuminuria. Recent studies have shown that TNF-R2 inflammatory pathway is predominantly involved in the progression of albuminuria during the early stages of diabetic nephropathy.

The levels of urinary TNF- $\alpha$ higher in diabetics with macroalbuminuria compared to those with microalbuminuria. These results are in agreement with Refat $\boldsymbol{e t}$ al. ${ }^{(8)}$, and Navarro et al. ${ }^{(12)}$, they observed significant differences in serum and urinary TNF- $\alpha$ and hs-CRP levels between patients with microalbuminuria and patients with macroalbuminuria, being higher among patients with macroalbuminuria. So our results showed that urinary TNF- $\alpha$ was independently and significantly correlated with the presence and degree of albuminuria in 
diabetic nephropathy in type 2 diabetes mellitus.

In our study, we found significant association between urinary $\mathrm{TNF}-\alpha$ and $\mathrm{HbA} 1 \mathrm{C}$ level. The reverse was found in the study of Refat et al. ${ }^{\left({ }^{(8)}\right.}$. They found significant association between serum, but not urinary $\mathrm{TNF}-\alpha$ and $\mathrm{HbAlC}$ level. They explained that the metabolic (hyperglycemia and oxidative stress pathway) affects the severity of the disease and its progression and hence systemic production of this cytokine, which could explain the correlation between metabolic control and serum TNF- $\alpha$. The observations of Navarro et al. ${ }^{(12)}$, support our finding, as they observed that urinary $\mathrm{TNF}-\alpha$ level but not serum was related to glycemic control (HbA1C) and they attributed their findings to the Refat et al. ${ }^{\left({ }^{(8)}\right.}$.

So further studies are required to confirm these associations.

\section{Conclusion}

The findings of the present study show that urinary TNF- $\alpha$ is independently and significantly correlated with the presence and degree of albuminuria in diabetic nephropathy in type 2 diabetes mellitus. This suggests that TNF- $\alpha$ plays a significant role in the pathogenesis and progression of renal injury in diabetes and urinary TNF- $\alpha$ excretion will be a good early marker of inflammation in diabetic nephropathy in type 2 diabetes mellitus.

\section{References}

1. American Diabetes Association (2004): Nephropathy in Diabetes. Diabetes Care. 27: 79-83.

2. Tuttle KR, Bakris GL, Bilous RW et al. (2014): Diabetic kidney disease: a report from an ADA Consensus Conference. Diabetes Care, 37:28642883.

3. Lampropoulou M, Stangou A, Papagiann I et al. (2014): TNF-alpha and Microalbuminuria in Patients with Type 2 Diabetes Mellitus. Hindawi Publishing Corporation, Journal of Diabetes Research, 394206: 7-15.

4. Sun $L$ and Kanwar YS (2015): Relevance of TNF- $\alpha$ in the context of other inflammatory cytokines in the progression of diabetic nephropathy. Kidney International, 88(4): 662-665.

5. Matheson M, Willcox J, Flagon $\mathrm{M}$ et al. (2010): Urinary biomarkers involved in type 2 diabetes: a review. Diabetes Metab Res Rev., 26(3):15071.

6. Kalantarinia K, Awad AS, Siragy HM (2003): Urinary and renal interstitial concentrations of TNF- $\alpha$ increase prior to the rise in albuminuria in diabetic rats. Kidney Int., 64(4):1208-1213.

7. Navarro JF, Mora C, Maca M et al. (2003): Inflammatory parameters are independently associated with urinary albumin in type 2 diabetes mellitus. Am J Kidney Dis., 45: 125-129.

8. Refat H, Mady G, El Ghany M et al. (2010): Correlation Between Tumor Necrosis Factor Alpha and Proteinuria in Type-2 Diabetic Patients. Arab Journal of Nephrology and Transplantation, 3(1): 4314-4321.

9. Mastej K, Adamiec $R$ (2008): Neutrophil surface expression of $\mathrm{CD} 11 \mathrm{~b}$ and $\mathrm{CD} 62 \mathrm{~L}$ in diabetic microangiopathy. Acta Diabetologica, 45(3): 183-190.

10. Navarro JF, Mora C, Muros M et al. (2011): Inflammatory molecules and pathways in the pathogenesis of diabetic nephropathy. Nature Reviews Nephrology, 7(6): 327-340.

11. Moriwaki T, Yamamoto $Y$, Shibutani T et al. (2003): Elevated levels of interleukin-18 and tumor necrosis factor-alpha in serum of patients with type 2 diabetes mellitus: relationship with diabetic nephropathy. Metabolism: Clinical and Experimental, 52(5): 605-608.

12. Navarro JF, Mora $\mathrm{C}$, Muros $\mathrm{M}$ et al. (2006): Urinary tumour necrosis factor-alpha excretion independently correlates with clinical markers of glomerular and tubulointerstitial injury in type 2 diabetic patients. Nephrol Dial Transplant., 21(12):3428-3434. 